\title{
Estampas y retratos de España en el Viaje de Sarmiento
}

\author{
Vicente CERVERA SALINAS \\ Universidad de Murcia
}

\begin{abstract}
RESUMEN
Este artículo revisa uno de los títulos más representativos de la bibliografía de Domingo Faustino Sarmiento (1811-2011): el Viaje a España, realizado en 1846. La visión crítica que plasma el escritor y político argentino de la sociedad española se articula a través de una dimensión plástica y estética, donde sobresalen las cualidades estilísticas de Sarmiento. El autor compone un mosaico con estampas, retratos, aguafuertes, alusiones pictóricas a la historia del arte español y descripciones de ciudades, gentes, costumbres y hábitos del pueblo español. Así, consigue constatar, a través de este museo de la incultura anclada en el retraso secular y en la renuencia española al soplo progresista del siglo XIX, la perspectiva de un "civilizado" que nunca dejó de sentir la fascinación literaria por los rostros de la "barbarie".
\end{abstract}

Palabras clave: viaje, España, Sarmiento.

\section{Sketches and Portraits of Spain in Sarmiento's Viaje}

\begin{abstract}
This article explores one of the most representative titles in Domingo Faustino Sarmiento's oeuvre: the narrative of his journey to Spain (Viaje), undertaken in 1846. The Argentinean writer and politician articulates, with extraordinary stylistic flair, a critical view of Spain founded on his aesthetic perceptions. Sarmiento puts together a mosaic of sketches, etchings, portraits, and painterly allusions to the history of Spanish art as well as descriptions of Spanish cities, people, customs, and habits. It adds up to a museum of ignorance and underdevelopment: the panorama of a country reluctant to open itself up to the progressive currents of the nineteenth century. In this way, Sarmiento conveys the perspective of a genteel intellectual who never failed to feel a literary fascination towards the faces of barbarism.
\end{abstract}

Keywords: trip, Spain, Sarmiento. 
En carta fechada el 15 de noviembre de 1846 al ilustre escritor chileno José Victorino Lastarria, aludía por primera vez Domingo Faustino Sarmiento al país que durante siglos fue metrópoli de las colonias americanas bajo el nombre de Aspaña ${ }^{1}$. La denominación cobraba el vigor de un preámbulo al relato del viaje a la Península Ibérica, en el seno de una serie de importantes desplazamientos por Europa, África y América, que llevara a cabo el escritor y político argentino durante aquellos convulsivos años que mediaban el siglo diecinueve. Implementaba asimismo un imaginario distintivo para aludir a sus impresiones por el territorio español, troquelando, al fin, un concepto bastante unitario de cuanto experimentó en su periplo y quiso verter a la escritura bajo la forma de un diario con destino epistolar.

Sostenía Miguel de Unamuno que hablar de Sarmiento era referirse a su propia generación hispana, en lo tocante a su visión diáfana del atraso español, de la ranciedad inconmovible de sus costumbres inveteradas y de los males político-sociales que hubo infligido en su historia del coloniaje americano. Como el más castizo de los escritores del XIX lo valora el autor de Por tierras de Portugal y España, alabando la fortuna de contarse entre los cultivadores más libres de la lengua castellana y entre los más encendidos y mordaces críticos con la cultura española, enquistada en un estancamiento infecundo. Como un "español que renegaba de España" lo bautiza en encendido elogio a su figura, como un hombre ilustrado y liberal que "quería borrar de su patria la tradición española, a la que atribuía los males de la Argentina", pero que supo hacer uso de su idioma de manera ejemplar: "Siempre que leo las invectivas de Sarmiento contra España" - exclama enfáticamente- "me digo: ¡Pero si este hombre dice contra España lo mismo que decimos los españoles que más y mejor la queremos! Habla sí, mal de

1 "Esta Aspaña que tantos malos ratos me ha dado, téngola por fin en el anfiteatro, bajo la mano [...]" (Sarmiento, 1996: 127). A pesar de tratarse de la edición crítica, que por supuesto he manejado y consultado para la escritura de este artículo, recurriré, a la hora de citar el Viaje de Sarmiento a España, a otra edición más antigua, porque no comparto el criterio de respetar la norma ortográfica de la época, como realizan los responsables de la edición crítica de Archivos, que nos llevaría a reproducir la "i" frente a la "y", entre otras incidencias, cuando hoy en día resulta obsoleto e innecesario. Es cierto que la voluntad del equipo coordinado por Javier Fernández es de respeto filológico a un texto que no nació con intención literaria ni histórica, sino como expresión espontánea de los apuntes de un viajero que redacta en cartas a sus amigos. También es cierto que Sarmiento no corrigió nunca las ediciones publicadas en vida, por lo que parece justo que exista una edición crítica y filológica que siga esas pautas. No obstante, y aun respetando el criterio de Archivos, que reproduce literalmente "el genio y la voluntad del autor y de su época [...] sin hacer ningún tipo de corrección ni actualización" ortográfica ni estilística, no es menos justificable el uso de ediciones donde la normal actualización ortográfica suponga una mejor fluencia lectora y un menor extrañamiento a la hora de citar aisladamente sus palabras. A pesar de ello, he de admitir que en ediciones como la que voy a establecer durante todo el texto, una edición argentina de 1922 -frente a la de 1886, en que se fija la edición crítica de Archivos-, se comete la incorrección innecesaria de modificar el neologismo irónico Aspaña por España, razón por la que he recurrido excepcionalmente a escoger la de Archivos para esa cita. 
España, pero habla mal de España como sólo un español puede hablar mal de España, pero lo hace en español y muy en español" (Unamuno: 198) ${ }^{2}$. Y así, una de las facetas más perdurables de su riqueza literaria será, para Unamuno, justamente la capacidad sarmientina para abocetar imágenes potentes y perfectamente definidas de los espacios y parajes que su mirada fue encontrando en el camino: en el de su propia tierra argentina y también en sus pintorescos viajes por Europa, África y los Estados Unidos de América. Esta cualidad, que podríamos definir como la veta plástica del estilo de Sarmiento, será especialmente vigorosa en las descripciones realizadas a través de su viaje por tierras españolas, al hilo de sus invectivas y a través de su afilada disección de la realidad circundante. Son características que desarrolló el autor en memorables páginas de $\mathrm{Facundo}^{3}$, como aquellas dedicadas a mostrar lo que él definió como el "costado poético" de la vida pastoril en la inculta pampa argentina y que habría de convertir en sustento estilístico en su autobiografía nacionalista-espiritual, Recuerdos de provincia. Sabía que eran imágenes nacidas "para quedarse hondamente grabadas" y, como él mismo se preguntaba, ¿qué más colores serían necesarios para ilustrar la paleta de la fantasía que aquellos nacidos de su propia experiencia visual y anímica?

El viaje a España no hará sino redundar en ese recurso que con suma destreza y habilidad supo manejar Sarmiento en tantas descripciones sobre la civilización y la barbarie en América, y que ahora no necesitaban sino trasvasarse a otro mundo, un mundo "viejo" y demacrado. Y así, según el juicio de autores como Enrique Anderson Imbert, el talento literario, la potencia descriptiva de Sarmiento, fue todavía más visible que en Facundo en las cartas que configuraron la escritura de sus viajes, pues en ninguna de sus otras obras "se abre tan a lo ancho y a lo hondo el alma de Sarmiento" con toda su gama de matices emotivos y colores verbales: "se siente" sintetiza el crítico y narrador argentino- "actor del mundo que describe: sus cartas son, pues, fragmentos de una novela virtual" (Anderson Imbert: 47).

${ }^{2}$ Comenta, a propósito de la "hispanofobia" sarmientina, Rubén Benítez: "Si esa actitud es antiespañola, lo es también la de escritores ilustres como Feijóo, Jovellanos, Moratín, Quintana, Blanco-White y, sobre todo, Larra, es decir la de todos aquellos heterodoxos que se han atrevido a discutir la supuesta ideología española. Con razón, Américo Castro une a esos nombres el nombre de Sarmiento como ejemplo del desvivirse hispánico" (Benítez: 720).

3 “De aquí resulta que el pueblo argentino es poeta por carácter, por naturaleza. ¿Ni cómo ha de dejar de serlo, cuando en medio de una tarde serena y apacible, una nube torva y negra se levanta sin saber de dónde, se estiende [sic] sobre el cielo mientras se cruzan dos palabras, y de repente el estampido del trueno anuncia la tormenta que deja frío al viajero, y reteniendo el aliento por temor por atraer un rayo de dos mil que caen en torno suyo? La oscuridad se sucede después a la luz: la muerte está por todas partes; un poder terrible, incontrastable le ha hecho reconcentrarse en sí mismo, y sentir su nada en medio de aquella naturaleza irritada; sentir a Dios, por decirlo de una vez, en la aterrante magnificencia de sus obras. ¿Qué más colores para la paleta de la fantasía? Masas de tinieblas que anublan el día, masas de luz lívida, temblorosa, que ilumina un instante las tinieblas, y muestra la pampa a distancias infinitas, cruzándola vivamente el rayo, en fin, símbolo del poder" (Sarmiento, 2001: 78-79). 
A este aspecto concreto del relato viajero de Sarmiento como "novela virtual" dedicaremos estas páginas, en la búsqueda de aquellas imágenes pictóricas más destacadas, vertidas en bocetos, grabados, estampas, pinturas y escenas pictóricas, apuntes, paisajes, alegorías visuales, emblemas, retratos y demás modalidades de la expresión gráfica que tan diestramente manejó nuestro literato en sus descripciones. Sabemos, además, que en su viaje español, Sarmiento fue acompañado durante una buena parte de su trayecto en diligencia por Karl Girardet, "hijo de una ilustre familia de artistas suizos" y Pharamond Blanchard, "colaborador del barón Taylor en la evaluación y compra de las riquezas artísticas de España incorporadas desde 1835 a la colección particular de Luis Felipe" con el encargo de pintar óleos para el Museo de Versalles (Benítez: 732). Ellos formaban parte de diversas comitivas enviadas por países europeos, especialmente por Francia, para reflejar pictóricamente los festejos celebrados con motivo de las bodas reales de la reina Isabel II con su primo el Infante don Francisco Asís de Borbón, en Madrid, durante el mes de octubre de $1846^{4}$. De hecho, el propio Sarmiento aprendió de M. Blanchard habilidades relacionadas con la captación visual de los hechos, puesto que habiendo sido "enviado por Luis Felipe para bosquejar los grandes actos del drama de Madrid para las Galerías de Versalles", poseía un conocimiento profuso de la realidad española, siendo "grande taurómaco" y pudiendo ofrecer a sus compañeros de viaje y contertulios, como lo era Sarmiento en aquella ocasión, "mil detalles picantes de las costumbres españolas que no están escritas en libro alguno." Durante el itinerario, como el propio argentino anota en sus cartas, que duró más de cinco días con sus noches desde Irún hasta Madrid, se sucedieron notables pláticas "sobre artes, viajes, historia" y diversas anécdotas de toda condición (Sarmiento, 1922: 11-12).

Apreciemos que la alusión al "arte" es la primera de las referidas por el autor, lo cual no es baladí, y a ello también obedecen las variadísimas y sorprendentes estampas literarias que irá desgranando el autor al hilo de la escritura de su periplo. En este sentido, parece asentir Sarmiento al dictum de Alejandro Dumas, con quien también coincidió en estas circunstancias, según el cual la búsqueda más importante de todo viajero no es la de la civilización del país visitado, sino la captación honda de "la poesía, la naturaleza, las costumbres" del mismo, por lo que no duda en reconocer Sarmiento el magisterio de quien consiguió plasmar, en sus Impresiones de Viaje, "el brillo de esta atmósfera meridional, cuyos violados tintes se agrupaban en el horizonte $\mathrm{y}$ en las ondulaciones de este suelo desnudo" (Sarmiento, 1922: 12). No es de

${ }^{4}$ En su excelente artículo, Rubén Benítez detalla los acontecimientos con abundante y prolija documentación histórica: "Desde meses atrás, al conocerse la secreta tramitación del noble matrimonio, la prensa europea había comenzado a difundir noticias sobre España y sobre el carácter de esa alianza matrimonial. [...] Al casarse Isabel con su primo que, según la prensa interesada, padecía de ciertas debilidades congénitas, era de esperar la falta de una sucesión legítima; en caso de morir los reyes, la corona pasaría, con ley sálica o sin ella, al príncipe francés, consorte de la única heredera" (Benítez: 729). 
extrañar, por lo tanto, que sean las estampas paisajísticas una de las modalidades que recrea el argentino en su recorrido visual por España. Analicemos alguna de ellas:

El aspecto físico de la España trae en efecto a la fantasía la idea del África o de las planicies asiáticas. La Castilla vieja es todavía una pradera inmensa en la que pacen numerosos rebaños, de ovejas sobre todo. La aldea miserable que el ojo del viajero encuentra, se muestra a lo lejos terrosa y triste; árbol alguno abriga bajo su sombra aquellas murallas medio destruidas, y en torno de las habitaciones, la flor más indiferente no alza su tallo, para amenizar con sus colores escogidos la vista desapacible que ofrecen llanuras descoloridas, arbustillos espinosos, encinas enanas, y en lontananza montañas descarnadas y perfiles adustos. (Sarmiento, 1922: 12)

Como cabe observar, incide Sarmiento en el correlato del alma geográfica castellana con los paisajes asiáticos o africanos, creados por su imaginación, como ya realizara en memorables secuencias de su Facundo, donde también insistía en prolongar la comparación de la geografía pampera con la de los desiertos orientales, cuyas soledades son equiparadas con las argentinas ${ }^{5}$. Imágenes notables de este cuadro son las captadas de los numerosos rebaños, con su inevitable guiño al caballero manchego cervantino ${ }^{6}$. En otras tantas sobresale la imagen estéril de la tierra, donde la ausencia de vegetación es dominante y la pobreza de colores torna la paleta del pintor en una gama "descolorida" de tonos pétreos, grises y ocres, destacando sobre el fondo homogéneo del paisaje la silueta de lo escaso ("encinas enanas") o de lo hiriente ("arbustillos espinosos") y raquítico ("encinas enanas"), para plasmar una imagen de pobreza y desolación. Tierra baldía para un pueblo llano y no menos parco en cultura, dominado por lo primitivo y atávico. Como los árabes y los "esclavones", los viajes por España están "amenizados" por la aparición de bandoleros, que portan carabinas y añaden ese rasgo de pintoresquismo novelesco. La reflexión que añade el argentino no puede ser más acre, al destacar el carácter

5 "Y, en efecto, hay algo en las soledades argentinas que trae a la memoria las soledades asiáticas; alguna analogía encuentra el espíritu entre la Pampa y las llanuras que median entre el Tigris y el Eúfrates; algún parentesco en la tropa de carretas solitaria que cruza nuestras soledades para llegar, al fin de una marcha de meses, a Buenos Aires y la caravana de camellos que se dirige hacia Bagdad o Esmirna. [...] Es el capataz un caudillo, como en Asia el jefe de la caravana: necesítase para este destino una voluntad de hierro, un carácter arrojado hasta la temeridad, para contener la audacia y turbulencia de los filibusteros de tierra que ha de gobernar y dominar él solo en el desamparo del desierto. [...] La árrea [sic] de mulas cae con frecuencia en manos de estos beduinos americanos y rara vez los troperos escapan de ser degollados" (Sarmiento, 2001: 62).

6 De hecho, en páginas posteriores de estos diarios habrá de referirse Sarmiento a los paisajes manchegos y a la ínclita figura de Quijano: "La diligencia pasa por Aranjuez adonde no he querido detenerme. A poco andar reaparece el desierto, el secadal de la Mancha, la venta de don Quijote, y los molinos de viento [...]. La venta de Puerto Lápice está intacta aún [...]" (Sarmiento, 1922: 54). 
inveterado del pueblo español y su propensión a languidecer y perseverar en su casticismo, sin dar paso a la novedad y al progreso. Se define así un destino de "destiempo" para el país en el concierto de las naciones civilizadas. Los "frutos tardíos" españoles de los que nos hablaría Ramón Menéndez Pidal no son sino una consecuencia metafórica de las meditaciones sarmientinas por los parajes de "Aspaña"?.

Las reflexiones sociológicas y aun etnológicas que prodiga el viajero acerca del territorio peninsular contienen el estampado de algunas escenas de corte expresionista y aun tremendista en que el escritor no escatima detalles ni circunstancias, empeñado en descubrir la osamenta originaria que sostiene la sociedad española, en cuya médula sobresale la pincelada goyesca y el estertor esperpéntico, tan nítidamente reconocidos por la sensibilidad mordaz de quien tan bien conociera los secretos del alma bárbara. Así pues, refiriéndose a la sociedad vasca y, más concretamente, a las guerras carlistas surgidas en el seno de las controversias dinásticas decimonónicas, plasma Sarmiento la siguiente escena de goyesca y negra filiación:

De tiempo en tiempo se avistan las tostadas ruinas de alguna aldea, saqueada, quemada y arrasada durante la guerra de los carlistas. ¿Qué horrores revelan estos vestigios!, ¡qué de crueldades inauditas han sido cometidas en estos lugares! Hace años que en América conversaba con un niño, hijo de un jefe carlista y enviado a América para librarlo de las represalias. Este niño me contaba lo que hacían él y una veintena más que seguían los ejércitos carlistas: "Una vez, decía, nos pusieron a cuidar como doscientos prisioneros cristianos. Les amarramos los brazos y nos divertíamos en sacarles los ojos y abrirles el pecho para verles palpitar el corazón. Después, los fusilábamos, apoyándoles en la frente la boca del cañón de las carabinas. (Sarmiento, 1922: 15)

La cualidad atroz de lo relatado condice con el ambiente de suma barbarie en que Sarmiento reconocía el costado más atroz y censurable del alma humana. El hecho de que se trate de la evocación de un relato incrementa la nota amarga, pues el recuerdo ha sido pulsado precisamente por asociación de crueldades, acaecida en el lar español, donde, de algún modo, pueden ser ratificadas de primera mano. Cabría aquí observar, como con acierto ya lo hiciera Rubén Benítez, que la finalidad última del viaje sarmientino por España no se debió a la consecución de objetivos políticos "en relación con las luchas rioplantenses" sino "para comprobar, como en una dolorosa peregrinación a las fuentes, el origen español de los males americanos" (Benítez:

${ }^{7}$ Santiago Kovadloff ha cotejado el binomio cultura-naturaleza en dos viajeros por España: Sarmiento y Víctor Hugo. Su conclusión nos interesa en este punto: “Así como a Sarmiento lo desespera la escasa distancia existente entre naturaleza y cultura de que da pruebas la España por él recorrida, a Víctor Hugo, en cambio, lo hechiza. Describiendo una casa de montañeses, en la zona de Guipúzcoa, a la que visitó en 1843, Hugo se deleita con la homologación entre naturaleza y cultura de la que el medio español le brinda generosas evidencias" (Kovadloff: 782). 
727). Y así, el recuerdo de lo ya conocido en territorio argentino vendría a ser corroborado por la constatación física del peregrino.

La virulencia de los horrores de la guerra aparece encadenada en el relato viajero con el apunte sobre las condiciones de insalubridad y desaseo en que habitan los moradores de importantes bastiones de la cultura hispánica, visitados por Sarmiento, como es el caso de la villa de Burgos, que es incorporada al relato de un modo irónico y mordaz. Señala el escritor que por fortuna la diligencia no llega a adentrarse en la ciudad sino cuando la noche cubre sus vergüenzas. Con un apunte libre y veloz, como un esbozo del dibujo que no precisa ser más tarde perfeccionado, plasma su impresión de la patria del Cid con estos rasgos: "Burgos, con su catedral gótica, se levanta cual sombra de los tiempos heroicos, como el alma en pena de la caballería española" (Sarmiento, 1922: 16). La sagaz punzada de Sarmiento es en este punto de una eficacia irreprochable, obedeciendo al precepto de un laconismo esencial como técnica de retrato y caracterización moral. No se trata ya de la recreación de un humanismo quijotesco, con su patente derroche de un tipo de vitalidad que, aun tardía como en el caso del hidalgo manchego, es al fin tierna y piadosa. Frente a ella surge en el aguafuerte de Sarmiento la imagen de una sombra, la del heroísmo transido, que alcanza la metáfora visual del "alma en pena", con todo su aparato de gótica deformación. Esa caballería es para Sarmiento una quimera sin materia ni contenido en los tiempos que le tocó reconocer las tierras castellanas. Y sin embargo la belleza romántica, que todavía le confiere el ambiente nocturnal a los monumentos y restos del pasado, ocasiona en su relato una interesante polaridad, por otra parte tan del gusto de su literatura, donde la dicotomía halla estatuto de técnica simbólica, y consiente tantas veces la inversión de sus valores ideológicos ${ }^{8}$. No olvidemos que Sarmiento fue, en su encendido denuesto, el máximo elogiador de la figura de Facundo. En este recuento de sus impresiones burgalesas se detecta una fórmula pareja de inversiones: "Burgos de noche es la vieja Burgos de las tradiciones castellanas, la morada del Cid, la Catedral gótica más bella que se conoce. De día es un pobre montón de ruinas vivas y habitadas por un pueblo cuyo aspecto es todo lo que se quiera, menos poético, ni culto, dos modos de ser que se suplen uno a otro" (Sarmiento, 1922: 18) ${ }^{9}$.

8 A propósito de la cuestión romántica, tan debatida en la obra de Sarmiento, señala Santiago Kovadloff: “¿Pero hasta qué punto logra Sarmiento, efectivamente, dejar atrás el romanticismo, desembarazarse de su influjo y superarlo? A nuestro juicio, con el romanticismo le sucederá a Sarmiento lo que a su país con España: por un lado, se lo ha quitado de encima; por otro, advertirá cuánto se asemeja a lo que tan encarnizadamente combate" (Kovadloff: 783-784). Según Dardo Cúneo, en su monográfico estudio comparativo entre Sarmiento y Unamuno, en la época del primero, como buen momento de mudanza y desajustes, "la actitud romántica persiste en manifestarse como un ejercicio de interpretación disidente de la realidad" (Cúneo: 160).

${ }^{9}$ Cfr.: "Era Sarmiento un bárbaro que creía en la civilización", nos dice al comenzar su magnífica semblanza Germán Arciniegas. Y lo corona en posteriores actualizaciones: "Pero lo que le dominaba era la pasión de leer. Leía, claro, como un bárbaro [...]. Pasó a unas minas y 
Civilizada, es decir, culta y poética, se muestra la urbe bajo la pátina de la bruma nocturnal, donde aún la "tradición" no es socavada por el jirón de verdad que la luz solar provoca al desgarrar el velo de belleza que la cubre. Cercana a una estampa romántica de Caspar David Friedrich, la imagen de la villa se halla aureolada por el prestigio de la poesía, pero esa misma visión se desgarra, se desvela -también románticamente- cuando la luz de sol rompe el hechizo para mostrar la realidad más descarnada y opuesta. En su visión meridiana de los pueblos, aldeas, parajes y soledades de España, la poesía va dejando paso a la galería de figuras grotescas y de endémica presencia en su geografía: los mendigos y los ciegos, que ilustrarán tantas páginas literarias de acendrada huella hispana, como en la novelística de Benito Pérez Galdós o en la filmografía de Luis Buñuel. Para Sarmiento el pasaje del paisano al mendigo es casi connatural en el pueblo español, ya que aquél posee "todas las cualidades necesarias" para ejercer tal "profesión". La veta pictórica del autor halla en este retrato una fuente de plasticidad digna de un preclaro artista del pincel, así como lo fue de la sarcástica pluma: "El paño burdo de que el pueblo español viste es de color y consistencia calculados para resistir a la acción de los siglos, verdadera muralla tras de la cual el cuerpo está al abrigo del sol, del aire y del agua, con la que está toda su vida peleado irreconciliablemente" (Sarmiento, 1922: 19). Como recapitula al respecto Hugo E. Biagini, cuando Sarmiento recorre con sus descripciones el panorama general del pueblo español, el resultado resulta "desolador, dotado con una atmósfera simple y rudimentaria, como si estuviera en medio del África o de Asia. Mientras se acusa la falta de caminos y transportes se subraya la abundancia de asaltantes y mendigos. Ello produce en Sarmiento la imagen de un pueblo brutal, decadente e inculto, lleno de remiendos físicos y morales, con enormes vacíos por cubrir" (Biagini: 98).

La aglomeración humana en las fiestas reales celebradas en Madrid dan lugar también a multitud de estampas y viñetas en el recuento que el argentino realiza de su viaje. El retrato de los personajes que concurrían a dichos festejos incorpora el color local y el tipismo pintoresco que puebla sus páginas. Así, la muchedumbre aglomerada supone un repaso de cuadros costumbristas, con los personajes más característicos del momento, entre los cuales descollaban figuras que podrían haber salido de los lienzos cortesanos de Francisco de Goya, donde "las altas y nobles damas, como las humildes fregonas, llevan aún la tradicional mantilla negra y transparente, que, con aire misterioso, cae sobre las espaldas, ocultando a medias los encantos femeninos" (Sarmiento, 1922: 22) ${ }^{10}$. Junto a ellas, destacan las alusiones a prendas o atuendos de gran calado en el tejido social español, como la capa, "de

fue capataz. En la Colorada, por la noche, en la cocina, daba lecciones de francés y castellano a los mineros. Leía hasta en el fondo de los socavones. Tradujo sesenta tomos de las novelas de Walter Scott. Un volumen por día. Era un bárbaro" (Arciniegas: 232-233).

10 "El costumbrismo campea hasta en los grandes libros de la primera época, Facundo, Viajes, Recuerdos de Viajes, como lo hemos visto. Y se puede averiguar la presencia del género a lo largo de toda la vida literaria de Sarmiento" (Verdevoye: 69). 
riguroso uso desde el mendigo, el pastor de ovejas y el muletero, hasta el comerciante de menudeo" o el sombrero calañés del sevillano, objeto que basta para colocar al español, por su raro y peculiar aspecto, "fuera de la familia europea, como aquellos subgéneros que descubres en plantas y animales los naturalistas". Resulta evidente que la pluma y el "pincel" del autor no escatiman ocasiones para subrayar los rasgos del exotismo hispano, siempre coaligados a su proverbial casticismo anclado en la tradición del inmovilismo. Por ello, la tesis sobre las raíces hispánicas, que determinan su peculiaridad cultural y lastran también su desarrollo civilizador, tiene tres vertientes complementarias: el sustrato romano, el elemento incorporado del mundo árabe y, por fin, el vetusto y todavía amargo sabor inquisitorial de sus costumbres y manifestaciones. De esta manera, su observación sobre la uniformidad del traje de origen religioso de las españolas le lleva a una asociación con las normas de convivencia ciudadana que la inquisición española impuso siglos atrás a la sociedad donde arraigó. Este aspecto capitaliza la ideología moral que sustenta el relato de su viaje por España. Prueba de ello será que ya, hacia el final del mismo, sintetice en un testimonio de conjunto las impresiones aludidas bajo una reflexión global:

Si yo hubiera viajado en España en el siglo XVI, mis ojos no habrían visto otra cosa de lo que ahora ven; lo conozco en el color de la piedra de los edificios, en la clase de ocupaciones del pueblo, en el vestido eterno y peleado con el agua que lleva, en la falta de todo accidente que indique el menor cambio debido a los progresos de las artes o de las ciencias modernas... (Sarmiento, 1922: 63).

Y del mismo modo, en sus notas sobre la Mancha, advierte ya con cierto escepticismo que "aquí, como en todo lo que de la España he visto, nada se ha cambiado después de tres siglos; Cervantes o Lesage escribirían hoy lo mismo" (Sarmiento, 1922: 54). Por esta razón, sus observaciones sobre la penuria cívica, social y económica de España remiten de manera constante a la huella del ambiente inquisitorial que rezuma en tantos factores de la realidad que observó Sarmiento en su viaje, como es la ausencia de estudios académicos importantes en ciencias naturales, en geología o en ciencias filológicas como el griego, "porque el clero no tenía afición a este idioma que introdujeron los laicos en Francia e Inglaterra" (Sarmiento, 1922: 62). A esta visión de un pueblo que no ha conseguido romper las cadenas del clericalismo corresponden sus defectos más arraigados y evidentes, como el aldeanismo, el chauvinismo o el desprecio a cuanto de extranjero, y por ende de extraño, penetre en sus lares. Quede puesto de relieve este extremo en los comentarios que realiza de las representaciones teatrales a las que asistió, donde el público exteriorizaba su "xenofobia" en las "tormentas de aplausos" que suscitaban las alusiones satíricas a los personajes extranjeros o extranjerizantes ${ }^{11}$. Con ironía rayana

${ }^{11}$ Al hablar de los "Tiempos modernos" en España, dirá: "El odio a los extranjeros hoy es el mismo que expulsó a los judíos y a los árabes” (Sarmiento, 1922: 63). 
en el sarcasmo, afirma que para el español "no hay más habitante del mundo que el francés y el inglés. Cree en la existencia del ruso; el alemán es ya algo problemático; pero eso de suecos o dinamarqueses, son mitos, fábulas, invenciones de los escritores que de ellos hablan" (Sarmiento, 1922: 44). Este grado de "inquisición" al pueblo español revelaría, inversa y paradójicamente, un signo de complementaria xenofobia, como ha hecho notar Hugo Biagini, si no fuera porque la pintura sarmientina no debió pecar de exagerada en sus apuntes y pinceladas, a pesar de su "autoritarismo etnocéntrico"12.

Sintonizando con el interés por el mundo oriental presente en tantos otros viajeros europeos del XIX (Nerval, Delacroix, Flaubert) ${ }^{13}$, recalca también Sarmiento la indeleble y aguda huella de "la dominación árabe" en el costumbrismo español. Este extremo representaría el mayor grado de atención que España produce en el extranjero, y sus preclaras manifestaciones cabe advertirlas "en los vestidos, en los edificios." La variedad de pobladores que pudo y supo aislar Sarmiento en su itinerario queda reflejados en estas impresiones: "En los bailes públicos, organizados para diversión del pueblo durante las fiestas, al lado de valencianos, aragoneses y gallegos, veíase figurar cuadrillas de moros, como si fuesen considerados todavía como parte de los pueblos españoles", relata Sarmiento (1922: 23), en clara alusión a manifestaciones festivas tan añejas como lo son los desfiles de moros y cristianos en tantas poblaciones peninsulares ${ }^{14}$. Por otra parte, y de modo complementario, las raíces romanas quedaron tan hondamente grabadas en la orografía española que "el pueblo español es el pueblo más romano que existe hoy día". Y aún es más: "Todos sus males vienen de ahí: enemigo del trabajo, guerrero, heroico, tenaz, sobre y apasionado por los espectáculos, todavía pide panen et circenses, para vivir feliz en medio de su caída" (Sarmiento, 1922: 24-25). Esta consideración etiológica sobre la proliferación del mal español fundamenta y cohesiona su discurso. Cabría incluso decir que vertebra el espíritu de su alegato y crítica, favoreciendo también la vertiente estética de su plasticidad discursiva: un escenario histórico-pintoresco es el causante de la realidad que el peregrino percibe y corrobora a cada paso. En este sentido, el viaje español de Sarmiento tendría una doble articulación genésica, que, debidamente

12 "Existiría una suerte de xenofobia invertida por la cual tienden a precipitarse en una misma redada, como elementos desechables, disímiles componentes locales y adventicios: el español de ultramar, sus descendientes acriollados y los hombres de color, para cerrarse el ciclo con los nuevos inmigrantes peninsulares en las postrimerías del siglo pasado" (Biagini: 109).

${ }^{3}$ Cfr.: Nieves Soriano: Viajeros románticos a Oriente: Delacroix, Flaubert y Nerval. Murcia, Editum, 2009.

${ }^{14}$ Más adelante, en la sección "Tiempos árabes", añadirá: "El español de hoy es el árabe de ayer, frugal, desenvuelto, gracioso en la Andalucía, poeta y ocioso por todas partes; goza del sol, se emborracha poco y pasa su tiempo en las esquinas, figones y plazas. Las mujeres llevan velo sobre la cara, la mantilla, como las mujeres árabes. Se sientan en el suelo de las iglesias, sobre un tapiz o alfombra con las piernas cruzadas a la manera oriental..." (Sarmiento, 1922: $61)$. 
tematizada, adquiriría la siguiente forma en el relato: si el origen del atraso americano reside en España, el de España procedería de Roma y el Lacio. Desde esta perspectiva, tan simplista como eficaz para su discurso, es posible acometer uno de los aspectos más llamativos del texto sarmientino, cual es la estampación de la fiesta taurina en sus páginas.

En la misma línea plástica de los grabados de tauromaquia de Francisco de Goya, enhebra Sarmiento la tesis de la filiación romana del espectáculo taurino, no sólo en lo que respecta a la secuencia y contenido de la misma, ni tampoco en lo relativo a la actitud del público asistente, sino también -y esto es lo que resulta más notable- en la supervisión de las autoridades, que con su presencia justifican y estimulan el acontecimiento festivo. Se sorprende así Sarmiento de que las corridas de toros tengan lugar "oficialmente y bajo la dirección inmediata de la autoridad". El código semiótico, regido por la autoridad real, se basa en un conjunto de gestos que remiten directamente a la tradición latina ${ }^{15}$. Este "carácter homérico" de la fiesta dota al folklore y costumbrismo hispanos de unos rasgos tan particulares como únicos, que lo desplazan del concierto de la "modernidad" en las naciones europeas. Recordemos, al respecto, el carácter paródico y satírico que la presencia del toro alcanza en textos literarios previos a Sarmiento en la literatura rioplantense, como el muy recordado relato de Esteban Echeverría, "El matadero"16, donde el esquema de la persecución, acoso y derribo al noble animal precedía y simbolizaba el motivo de la tortura y martirio del personaje del unitario por parte de la chusma de matarifes y federales congregados en el matadero, espacio donde se ritualizaba la ceremonia sangrienta del fanatismo rosista ${ }^{17}$. En el caso de Sarmiento, la descripción de este ceremonial de la muerte retrata la psicología social de un pueblo esclavizado por sus bárbaras tradiciones e incapaz de reinventar su historia. El sarcástico comentario con que sintetiza sus impresiones revela este signo moral de sus descripciones: "La noche halla a los espectadores agitándose sobre los bancos, y pidiendo a voces nuevas carnicerías y nuevos combates. Id, pues, a hablar a estos hombres de caminos de

15 "El gobernador de Madrid, en circunstancias ordinarias, y el rey en persona en las grandes solemnidades, presiden y dirigen todos sus movimientos. Un alguacil viene a pedir permiso para comenzar la función; este empleado público anuncia en alta voz el color del toro que va a jugarse, la señal particular, con que está marcado y la célebre torada a que tiene el honor de pertenecer; él abre, en fin, oficialmente la puerta del toril, cuya llave ha recibido de manos del rey. Cuando los picadores han atormentado por mucho tiempo a la fiera, a fin de debilitar su empuje, el rey hace una seña, y los banderilleros aparecen; a otro signo ceden éstos su puesto al matador que se presenta con la espada en la mano" (Sarmiento, 1922: 25).

${ }^{16}$ Como sabemos, escrito a finales de la década de los años treinta del siglo XIX, si bien publicado ya en la década de los setenta.

${ }^{17}$ No es la única comparación que cabe establecer con el gobierno de Rosas, objeto de sus reflexiones políticas en Facundo. De un modo ya explícito, nos dirá casi al final del relato de su viaje español: "La aduana española ha adoptado el vapor como medio de persecución, cual Rosas la prensa" (Sarmiento, 1922: 64). 
hierro, de industria o de debates constitucionales!” (Sarmiento, 1922: 27) ${ }^{18}$. Al igual que Sarmiento, Echeverría despuntó en su pericia para la descripción del escenario en que se desarrollaba su relato, ese "matadero" sanguinolento y cruel, un modelo plástico en la composición literaria que se asemejaría estética e ideológicamente a muchas páginas de Sarmiento y, en especial, de su Viaje español. Como Sarmiento, el efecto visual es el factor decisivo para activar la imaginación crítica de los lectores:

El espectáculo que ofrecía entonces era animado y pintoresco, aunque reunía todo lo horriblemente feo, inmundo y deforme de una pequeña clase proletaria peculiar del Río de la Plata. Pero para que el lector pueda percibirlo a un golpe de ojo, preciso es hacer un croquis de la localidad. (Echeverría: 98)

Con su habitual perspicacia, Pedro Henríquez Ureña definió en breves rasgos a Sarmiento, destacando que poseía "el ímpetu romántico pleno, la energía de la imaginación y el apasionado torrente de palabras, junto con vivaz percepción de los hechos y rápido fluir del pensamiento" (Henríquez Ureña: 163) ${ }^{19}$. Esos rasgos, combinados y transmutados en visión del mundo y estilo personal, favorecen curiosidades en el universo sarmientino, que no escapan a la redacción de sus viajes, como es el hecho de mostrar una clara ambivalencia de juicio moral y aun estético en el asunto que nos concierne sobre la fiesta taurina española. Y así, la censura del espectáculo que le lleva a establecer una ecuación histórica, sita en la Plaza Mayor de Madrid, entre los autos de fe y las corridas de toros; pero, al mismo tiempo, no puede reprimir un sentimiento creciente de fascinación, también a caballo entre la moral y la estética, por el ritual que observa, y que se convierte en uno de los elementos más y mejor desarrollados en las páginas de este viaje. Su cualidad de escritor retratista halla en esta situación su grado más álgido de perfección descriptiva, y el papel se torna por momentos lienzo de metáforas visuales, donde "la plaza se asemeja a un

18 También Rubén Benítez ha comentado algunas de las escenas retratadas por Sarmiento a propósito de la fiesta taurina. Observa, por ejemplo, el movimiento "de abajo hacia arriba" que preside la descripción de los "cuarenta mil espectadores", destacando el uso de sintagmas como "golpe de vista" o "espectáculo verdaderamente imponente". Según Benítez, "la cercanía de Blanchard debió facilitar esa pericia descriptiva. El grabado de Blanchard que ilustra las ediciones de la obra de Dumas, en el que se reproduce desde la misma perspectiva el engalanado palco real, con la inconfundible figura de la reina, y los palcos laterales ocupados por los dignatarios y militares uniformados, fija plásticamente estas sensaciones temporales" (Benítez: 744).

${ }^{19}$ Rasgos que apunta en sus Corrientes literarias de la América hispánica (1946), donde a colación de sus Viajes - comenta en nota a pie de página el erudito dominicano: "Cuando Sarmiento emprendió su viaje a Europa y los Estados Unidos, uno de sus propósitos era descubrir, estudiando la situación de España, las causas de las enfermedades políticas y culturales de la Argentina [...], y, estudiando el desarrollo de los Estados Unidos, el método para hacer triunfar la democracia. Mantuvo siempre su fe política, pero no cerraba los ojos ante hechos sociales que impiden la perfección del sistema democrático" (Henríquez Ureña: $165)$. 
gran claustro y las calles que de ella parten, arrancan por debajo de arcos triunfales que conservan la continuidad de los edificios que la circundan, ocupando uno de sus costados un palacio de arquitectura del renacimiento, recargado de adornos, torrecilla y pináculos." El elemento artístico se trueca en función festiva, y el escritor se rinde ante la metamorfosis del espacio: "El ámbito de esta plaza servía esta vez de digna arena para los toros reales" (Sarmiento, 1922: 29). La "dignidad" subraya un giro sutil en la perspectiva del viajero, que no duda en sincerarse en sus consideraciones, por más que su condición "civilizada" frene la seducción casi hipnótica que le embriaga:

He visto los toros, y he sentido todo su sublime atractivo. Espectáculo bárbaro, terrible, sanguinario, y sin embargo, lleno de seducción y estímulo. ¡Imposible apartar un momento los ojos de aquella fiera, que con movimientos peristálticos de la cabeza, está estudiando el medio de alzar en sus cuernos afilados al elegante toreador que tiene delante! ¡Imposible hacer andar la sangre que se aglomera en el corazón del extranjero novicio, mientras que, con rostro pálido, boca contraída y reseca, y ojos estáticos, está esperando el desenlace de la lucha para respirar, con aquel gemido que arrancan las torturas del espíritu! ¡Está Vd. como una cera, decía yo a un amigo francés...! (Sarmiento, 1922: 35)

Se trata, en el fondo, de una experiencia de alto voltaje, de incontrolable intensidad, donde se manifiesta la "necesidad de emociones que el hombre siente" (Sarmiento, 1922: 35), sintagma axial en el estilo humano y literario del romanticismo del autor. La cualidad literaria del ensayista y político argentino se potencia claramente en estas páginas de sus viajes, pues en ellas pudo más "el placer de contar que el móvil político" (Anderson Imbert: 47), por más que su programa ideológico estuviera presente como propedéutica. Por ello, da vía libre a su exaltación ante el teatro festivo y cruel de la tauromaquia, y no duda en exclamar que esa necesidad de emociones queda cubierta y satisfecha con los toros "como no satisface el teatro, ni espectáculo alguno civilizado". Se comprende así de modo diáfano la naturaleza contradictoria y, por ende, moderna del alma de Sarmiento. Esta dicotomía es el manantial de reflexiones de tono ensayístico donde, al cabo, acomete su discurso sobre la definición del género humano, como una genealogía de la barbarie, "porque no ha de conservarse un espectáculo bárbaro, sin que todas las ideas bárbaras de las bárbaras épocas en que tuvieran origen vivan en el ánimo del pueblo" (Sarmiento, 1922: 37). Y de ello infiere su catalogación humanística, muy en la línea del ensayismo hispanoamericano decimonónico, donde autores como José Martí conjeturaban la causa del caudillismo existente en los países americanos a partir de reflexiones sobre lo autóctono y el respeto a lo propio ${ }^{20}$. Decreta Sarmiento:

20 "Por esta conformidad con los elementos naturales desdeñados han subido los tiranos de América al poder, y han caído en cuanto les hicieron traición. Las repúblicas han purgado en sus tiranías su incapacidad para conocer los elementos verdaderos del país, derivar de ellos la forma de gobierno y gobernar con ellos. Gobernante, en un pueblo nuevo, quiere decir creador.” Palabras para "Nuestra América” de José Martí en 1891 (Martí: 160). 
Es para mí el hombre un animal antropófago de nacimiento que la civilización está domesticando, amasando, de cuatro o cinco mil años a esta parte; y ponerle sangre a la vista, es solo para despertar sus viejos y adormecidos instintos. Los espectáculos patibularios suscitan criminales en lugar de servir de escarmiento [...]. El hombre, además, tiene tantos instintos malos como buenos, y un sistema de creencias y de espectáculos, esto es, de ideas y de manifestaciones, puede formar irrevocablemente el carácter de un pueblo. No es otro el secreto de los gobiernos corruptores: la sociedad los apoya, aplaude y ayuda; en ella misma encuentran sus instrumentos que son todos los hombres, porque todos tienes su lado malo. (Sarmiento, 1922: 37)

Esta reflexión de filosofía política consiente tonos de vibración ensayística europea (pensemos en Montaigne ${ }^{21}$ ), pero en el fondo activa una tendencia en el autor al adoctrinamiento, ante la que él mismo reacciona, sabedor de que sus páginas de diario viajero están encaminadas a fines más literarios que educativos, a pesar del trasfondo "civilizador" del que partieron. La tendencia, en fin, al testimonio de impronta estética termina subrayándose por encima de todas las cuestiones educativas o ideológicas, y así su excurso sobre la naturaleza humana no resulta más convincente que sus propias pinceladas en rojo y magenta con que remata su dibujo tauromáquico, y en su visión del traspaso histórico que articula la historia de España, "el pueblo pasaba de la plaza Mayor de ver quemar vivo a un hereje, a la plaza de Toros, a ver destripar caballos, ensartar y sacudir toreadores en las altas, o morir veintenas de toros y caballos, entre charcos de sangre, y de excrementos derramados de los rotos intestinos. Yo he visto en una tarde morir diez y ocho caballos y siete toros, y dejo a cualquiera que calcule la cantidad de sangre que a chorros ha debido salir de veinticinco cuadrúpedos" (Sarmiento, 1922: 36-37).

El lienzo rezuma tonos expresionistas, más allá de los lineamientos tremendistas del retrato. Esa estética pre-expresionista de la que supo usar Sarmiento, como en tantas páginas de su Facundo, es una de las claves que caracterizan el estilo literario de sus Viajes. Pero en otras páginas ese expresionismo deriva hacia una técnica cercana al claroscuro tenebrista, más propio de la pintura barroca y manierista, como podría hallarse en algunos lienzos del Tintoretto o del Greco. Así sucede con su muy conocida descripción del monasterio de El Escorial, uno de los episodios, o una de las pinturas, más memorables de su viaje por España. Rubén Benítez ha sintetizado de modo diáfano la polaridad que vamos recorriendo desde el prisma estético de Sarmiento: "En el Escorial halla el sepulcro sombrío de la libertad de pensamiento; en la corrida de toros adivina un acto ritual de origen remoto, [...] en el que se manifiesta claramente el espíritu de la barbarie" (Benítez: 727). Pero, aún más allá de esta contraposición, resulta deslumbrante avanzar por "aquella pampa salvaje" de la mano

21 "Las obras escritas de Montaigne y Sarmiento difieren sustancialmente con respecto a la función social. Sus respectivos estilos ensayísticos nos proporcionan una base para la comparación: para ambos, el libro y el hombre estaban íntimamente ligados; para ambos, la escritura constituía una parte integral de aquel proceso al cual cada uno había decidido dedicar su energía primaria" (Katra: 91). 
(desde la visión) de Sarmiento, reconociendo en ella el páramo geográfico que dista desde la villa de Madrid hasta el monumento escurialense, ese "valle sin agua y sin árboles" en que se yerguen "la cúpula y torreones del edificio sacerdotal". Antes de visualizar su imagen, todavía se detiene Sarmiento en el relato de una anécdota que añade horror al retrato: "Al llegar a aquel páramo os enseñan un peñasco desnudo en que Felipe II hizo ahorcar a los trabajadores que no querían conformarse con el escaso estipendio que les había asignado" (Sarmiento, 1922: 48). Toda la página rezuma inspiración literaria y concreción plástica, encaminando todos sus atributos como escritor para definir, "ut pictura poesis", el cuadro más sombrío desde su impresión subjetiva:

Habréis oído decir que el Escorial está construido en forma de parrilla en honor de San Lorenzo y de la batalla de San Quintín; todo esto puede ser, pero ningún mal hace a la arquitectura este sombrío y bárbaro plan. Es la montaña vecina quien aplasta y anonada el monumento, dándole una alma oprimida, helada, torva. Por la mañana no está el sol allí para creerse uno libre; el frío, que bajo aquellas bóvedas sepulcrales penetra hasta los huesos, tiene no sé que de calabozo, de subterráneo, que os hace procurar, involuntariamente, las puertas, mirar las ventanas, buscando, como las plantas, la luz del cielo. (Sarmiento, 1922: 48)

¿Qué mejor manera de pintar, de manifestar a la luz, de extraer a la vista el espíritu del Escorial sino a través de esa "alma oprimida, helada, torva" que, en la mirada del viajero, lo contiene, anonadado por el rigor de la montaña vecina? Las sensaciones térmicas acompasan la sensación de desabrimiento que invade al lector (al contemplador del lienzo tenebrista). Esta imagen, este cuadro vivo de una parte simbólica de España, queda más vívido en la retina imaginaria de los lectores del "viaje" que la posterior vivisección histórica del monumento realizada por el escritor. Una imagen que lo transforma no ya en la "pirámide elevada al último representante de una forma de civilización" sino en "el trono para los que iban a heredar el poder de Felipe II y de la Inquisición": sudor de España y botín de guerra en homenaje de un poder bárbaro vinculado con la propia barbarie que, desde siempre desde la perspectiva de Sarmiento, supuso buena parte de la acción civilizadora de la Península Ibérica por las tierras sudamericanas. El lienzo se torna, al cabo, retrato oscurantista, propio de la escuela pictórica española de la misma época del emperador Felipe II, expresión plástica que exhibe bajo las "bóvedas sombrías" del monasterio "la historia de esta pobre enferma", que no es sino la nación española, cuyos síntomas trata de diagnosticar Sarmiento a través de su viaje, con la paleta de su escritura como bisturí $^{22}$.

${ }^{22}$ No resulta ocioso recordar el comentario al respecto de Hugo Biagini: "El Escorial, un cadáver con el alma atenazada, que sirvió de simbólica sepultura al poderío español, al desarrollo colonial, a la libertad de pensamiento, a las letras y las bellas artes, al conocimiento riguroso" (Biagini: 96). 
Como consta en el Diario de gastos que meticulosamente apuntaba el argentino en sus recorridos viajeros $-\mathrm{y}$ que tan acertadamente incorpora como apéndice la edición de la colección Archivos de los Viajes-, Sarmiento pagó el 10 de noviembre de 1846 sus buenos reales de vellón por la adquisición de estampas y láminas adquiridas en su visita al Escorial, entre las que se cuentan reproducciones de lienzos tan famosos como "La Magdalena" de Murillo o "Los borrachos" de Velázquez, así como otras de escuelas italianas como el "Moisés salvado de las aguas", del Veronés, cuyos originales pudo disfrutar en el "Real Museo" (hoy, Museo del Prado) de Madrid (Sarmiento, 1996: 508-509) ${ }^{23}$. Esta propensión plástica de Sarmiento se manifiesta tanto en estas circunstancias específicas como en la propia textura estilística de su viaje por España, según vamos observando en estas páginas. Expresa en bastantes momentos sus juicios y opiniones en materia de pintura española. Sus comentarios sobre la pintura del Museo madrileño le lleva nuevamente a contrastar la originalidad y pujanza del arte español del barroco "que se petrificó en el Escorial": los nombres eximios de Rivera (sic) y Velázquez quedan aunados a los de otros "pintores" de costumbres sobre el escenario teatral, como Lope de Vega y Calderón de la Barca (Sarmiento, 1922: 51). A partir de la petrificación contrarreformista, que acrisola el robusto monumento escurialense, el brillo artístico español "no dio una sola gota de jugo". Es más, cree reconocer a cada paso las imágenes vivas que personifican los grandes lienzos del arte español ya periclitado. Así, "los originales de Murillo se encuentran a cada paso en las manolas sevillanas; San Jerónimo en los mendigos desnudos; y en el cuadro de los Borrachos de Velázquez, vese que ni la fisonomía, ni el vestido de este tipo ha cambiado un ápice en tres siglos". Frente al estudio del pasado clásico, propio del arte italiano, España creó su arte de modo original y sustantivo, sin legar tampoco sus frutos a los posibles continuadores del ciclo histórico en la secuencia temporal del arte. La ausencia de arte estatuario queda explicada en la ausencia de una "atmósfera de gloria, que para elevar el alma suple a la libertad" (Sarmiento, 1922: 53), y el signo -y sino- "sacerdotal y despótico" de la España sarmientina habría impedido "levantar una sola estatua a las glorias mundanas". Los grandes genios, en fin, se mantienen como ínsulas extrañas en el devenir cultural y artístico español, inspirando tan sólo a los artistas extranjeros: "La novela creada por Cervantes fue a reproducirse en Francia; el pincel de Rivera (sic) en los países bajos" (Sarmiento, 1922: 52).

Exceptuando los esfuerzos civilizadores de Carlos III, y la constancia de que, puestos los pies en la ciudad de Barcelona, se hallaba por fin "fuera de España", el saldo de la visión hispana de Sarmiento resulta de una pobreza desoladora. Los

${ }^{23}$ La curiosidad artística y pictórica de Sarmiento se combina con otro tipo de intereses, que hoy denominaríamos más morbosos, de los que también queda testimonio en su "Diario de gastos", y que evidencian esa tendencia hacia lo expresionista anteriormente mentada. Así, el 12 de noviembre del mismo año 1846, en Córdoba pagaría 3 reales de vellón por "ver un niño con dos cabezas, tres piernas, tres brazos, ocho dedos en una mano" (Sarmiento, 1996: 509). 
"bárbaros cristianos" (Sarmiento, 1922: 59) destruyeron los restos de la civilización romana y árabe. En la Mezquita de Córdoba, "la más desamparada de las ciudades que han sido y no son nada" (Sarmiento, 1922: 57), desaparecieron los telares y las exquisitas "colgaduras de terciopelo de la seda que se cultivaba en los alrededores" (Sarmiento, 1922: 59). Y, sin embargo, "al salir de España", ya no aparece solitaria la imagen de esa "Aspaña" apuntalada por la invectiva y el punzón satírico. Frente al paladeo estético que rezuma en las viñetas, lienzos y aguafuertes con que ha atrapado la esencia "bárbara" y romántica del pueblo español, otra coloración aguarda bajo la acidez de su diatriba. Como muy bien recordaba Ricardo Piglia, el papel fundacional de la literatura de Domingo Faustino Sarmiento es indiscutible en la historia cultural argentina, debido, entre otras características, a esa "máquina polifacética", activa en su universo y su discurso ${ }^{24}$, y no sólo en el Facundo, sino en otros textos seminales en las letras rioplatenses, como son los Viajes. La variedad, el colorido, la tensión paradójica entre la crítica y la fascinación, la aureola fantástica y el componente progresista y cívico son rostros de ese engranaje variadísimo $-\mathrm{y}$ sin duda todavía instructivo en la actualidad- que compone el rico y pintoresco tapiz de sus relatos viajeros. Los cuadros que aboceta el autor, los garabatos y bosquejos que se suman a los más precisos lienzos de su brillante paleta siguen resultando deslumbrantes para la imaginación y enriquecedores para el conocimiento, tanto del personaje que los retrató como de la España que descubriera. Y, en la misma línea de sus contrastes marcadísimos, nos queda el sombrío y torvo gesto de la España de las hogueras junto a la deslumbrante alegría de los aforismos con que Sarmiento sintió reasumir su espíritu al abandonar el solar de la historia. Un muestrario de postales tópicas que saciarían la visión de quien no hubiera conocido nunca la tierra española, con más viveza que la propia de un pincel:

En Córdoba y Sevilla aquella arquitectura de mimbres bordada de arabescos, lo más risueño que con estuco han podido hacer los hombres; en la Andalucía los olivares; en Valencia, la Huerta regada por canales y con una legislación democrática, sumaria, a la luz del sol, que recuerda todavía el estrado, el diván, la puerta de calle en que los árabes administraban justicia. Y luego, las mujeres andaluzas, graciosas como bayaderas, locas por el placer como las orientales, y aquel pueblo que canta todo el día, ríe, riñe y miente con un aplomo que asombra. ¡Oh! Las hipérboles andaluzas dejarían atónitos a los más hiperbólicos asiáticos. ¡Qué imaginación, qué riquezas de espíritu! ¡Qué feliz en la alegre Andalucía!

Al salir de España, siento que toda ella se reasume en mi espíritu en estos raros aforismos. (Sarmiento, 1922: 59)

24 "La forma del Facundo me hace pensar en "la máquina polifacética" de que habla Roberto Arlt. El Facundo es una máquina polifacética: tiene circuitos, cables, funciones variadísimas, está llena de engranajes que conectan redes eléctricas, trabaja con todos los materiales y todos los géneros. En ese sentido funda una tradición” (Piglia, 1986: 47). 


\section{BIBLIOGRAFÍA}

ARCINIEGAS, Germán.

1961 América mágica. Buenos Aires: Editorial Sudamericana.

ANDERSON IMBERT, Enrique.

1977 “Sarmiento y la ficción”, Sur, Buenos Aires, julio-diciembre: 45-54. BENÍTEZ, Rubén.

1996 "El viaje a España", en Viajes por Europa, Africa i América, 18451847. Ed. de Javier Fernández (coord.), ALLCA XX-UNESCO. Colección Archivos, pp. 717-757.

BIAGINI, Hugo E.

1989 "Sarmiento y la problemática español", Cuadernos Hispanoamericanos, Madrid, abril, "Los complementarios/3": 93112.

CÚNEO, Dardo.

1981 Sarmiento y Unamuno. Buenos Aires: Belgrano.

ECHEVERRÍA, Esteban.

1986 El matadero. La cautiva. Ed. de Leonor Fleming. Madrid: Cátedra. HENRÍQUeZ UREÑA, Pedro.

2007 Historia cultural y literaria de la América hispánica. Ed. de Vicente Cervera Salinas. Madrid: Verbum.

KATRA, Willian.

1989 "El estilo ensayístico de Sarmiento", Cuadernos Hispanoamericanos, Madrid, abril, "Los complementarios/3": 83-92.

KOVADLOFF, Santiago.

1996 "España en Sarmiento. La herencia colonial y su influjo en la organización de la Argentina independiente", en Viajes por Europa, Africa i América, 1845-1847. Ed. de Javier Fernández (coord.), ALLCA XX-UNESCO. Colección Archivos, pp. 759-789.

MARTí, José.

2004 Ensayos y crónicas. Ed. de José Olivio Jiménez. Madrid: Cátedra.

PIGLIA, Ricardo.

1986 Crítica y ficción. Buenos Aires: Seix-Barral.

SARMIENTO, Domingo Faustino.

1922 Viajes II. España e Italia. Buenos Aires: Vaccaro.

1996 Viajes por Europa, Africa i América, 1845-1847. Ed. de Javier Fernández (coord.). ALLCA XX-UNESCO. Colección Archivos.

2001 Facundo. Ed. de Roberto Yahni. Madrid: Cátedra.

VERDEVOYE, Paul.

1977 "Costumbrismo y americanismo en la obra de Domingo Faustino Sarmiento", Sur, Buenos Aires, julio-diciembre: 55-69.

UnAMUNO, Miguel de.

1977 "Domingo Faustino Sarmiento", Sur, Buenos Aires, julio-diciembre: 196-199. 